\title{
Inclusive School Is (Not) Possible - Pupil's Voice
}

\author{
Slavica Pavlović \\ Department of Education, Faculty of Science and Education, University of Mostar, Bosnia and Herzegovina
}

Copyright $(2016$ by authors, all rights reserved. Authors agree that this article remains permanently open access under the terms of the Creative Commons Attribution License 4.0 International License

\begin{abstract}
Inclusive education has been the focus of a number of research studies in Bosnia and Herzegovina. However, most of the research was based on the teachers and to a lesser extent on parents' attitudes towards inclusive education, while pupils' views and voice were mainly neglected. The core of this paper is survey research on primary school pupils' attitudes towards inclusive education in general. The research was conducted using a five-point Likert-type scale, in the first half of 2014, on a convenient, stratified sample consisted of 300 pupils attending the final year of two primary schools in Mostar (Bosnia and Herzegovina). Findings revealed a negative attitude of the pupils, as a result of their lack of adequate information on inclusive education and its benefits. This seemed to result a sense of being neglected in the school itself in which their opinion(s), idea(s) and voice(s) have been neither asked for nor listened to although they expect it from their teachers. On the other hand, a positive attitude of the pupils was noticed in terms of their willingness to help the special needs pupils, who should be perceived as an important resource on which inclusive education could be built and/or improved in our schools.
\end{abstract}

Keywords Primary School, Pupils, Attitudes, Inclusive Education, Partnership

\section{Introduction}

Only themselves understand themselves and the like of themselves, as souls only understand souls. (W. Whitman [1])

Inclusion is a process, way of thinking, outcome for which a lot of efforts are necessary to be achieved. And yet, when speaking about inclusion, Bach (2005) [2] argued that it is quite a difficult task to achieve full educational and social inclusion for all the community members.

However, there are a number of efforts to involve and include special needs pupils and those with disabilities into regular schools, in particular primary ones. Teachers and their co-operational, communicational and didactic abilities as well as pupils' involvement are very important not only for schools themselves, but also for establishing social contacts within out-of-school relations (Gudjons, 1994) [3].
The essence of an inclusive education is a joint vision producing the necessary changes, new directions, guidelines as well as the outcomes representing benefits for all the subjects involved and the entire society, as well. It is the process of putting together the people, ideas, systems, communications, technologies, etc. As Medeghini and Valtellina (2006) [4] claim, the social nature of inclusive schools '... requests not only a passage related to what, but also to whom: in fact, inclusion addresses to all those who participate in the institutional and social life' (p. 98) [4], in our case in a would-be inclusive school.

According to Giangreco's [5] works, remarkable impacts of inclusive education are evident for broader communities, including pupils without disabilities. Some of those impacts are '...increased appreciation of human diversity, increased responsiveness to the needs of others, with and without disabilities, increased comfort interacting with people with disabilities, new relationships and friendships, social/emotional growth..., developed ethics/values of caring and commitment to others...' (1997, p. 203) [5] as well as new opportunities for contemplating and solving life problems, personal growth and all that without interference with the quality of their academic achievement.

On the other hand, the exclusion of pupils from decision-making seems traditional, as stated by Rudduck et al. (1997, according to Cox, 2005) [6], due to a deeply rooted perception that '...fails to acknowledge children's capacity to reflect on issues concerning their lives.' (p. 58) [6]. Hereby the hidden curriculum leads in various ways and in a number of schools to, what Marsh (1994) [7] calls, students' alienation.

For Eisner it is crucial to ponder whom the schools serve to, 'The school serves the teachers who work there as well as the students who learn there' (2002, p. 577) [8]. In that context, and with the reference to this paper's focus, 'the kind of schools we need ... would help students learn how to participate ... in taking gradually more and more responsibilities and becoming... the architects of their own education' (Eisner, 2002, p. 582) [8]. Is it a case in our school reality?!

However, consider the possibility of the reverse of this. Why not also take into consideration pupils' views and voices, their true inclusion into different segments of a school's everyday life, and beyond instruction? 


\section{Educational Reform - Revolution or Evolution of the Educational System...}

The core of educational reform in Bosnia and Herzegovina is based on three documents. All three point to inclusive education as a crucial issue, but focus mainly on the children, i.e. pupils with special needs, and developmental difficulties. Following the topic of this paper, some of the legislative points related to inclusive education will be summarized here.

The Organization for Security and Co-operation in Europe (OSCE), through its Council of the Peace Agreement, brought in its document entitled Education Reform (2002) [9] that includes various pledges, and goals to be achieved within quite precise deadlines indicated in the document itself. Here are some of those pledges:

'We will associate all the education stakeholders in these reforms, including students, parents, and teachers, in a democratic and transparent manner. (p. 8) [9] ... including children with special needs at all levels of the education system (p. 9) [9]... assess the number of children with special needs ... in order to determine the challenges that impede their inclusion into the general classroom (deadline: December 2003) ... develop a plan to educate community (including school boards, teachers, parents and students) with respect to the inclusion of children with special needs at all levels of the education system ... (deadline: August 2005) (p. 10) [9]; ... to ensure that schools are managed in a modern, democratic and inclusive manner: ... develop terms of reference for Parents' and Students' Councils (deadline: 2003), and establish s Parents' Council and a Students' Council in every school...' (p. 13) [9]

The OSCE Education Reform [9] document explicitly stated activities to be launched and accomplished in order to implement inclusive education successfully, apparently through the active participation of all the relevant stakeholders, pupils/students as well. After more than a decade there is still a question of whether any of these pledges has been fulfilled.

Another important document is The Framework of Law on Primary and General Secondary Education in FBH (passed in June 2003) [10], followed by single cantonal laws, all of them with an emphasis on their implementation to begin not later than June 2004. It means, from today's point of view, all the prerequisites (staff training, facility modifications, informing of the parents and broader community, ensuring of financial provisions, etc.) should have been accomplished in one year only. Here are some provisions of the Law regarding pupils' participation, with particular reference to inclusive education:

'Children with special needs shall be educated in regular schools and according to their individual needs...' (Art. 19, p. 7) [10].

In the Part VI - Role and Obligations of the School [10] it is explicitly quoted:

'School, parents, children ${ }^{1}$ and local community

1 Children are omitted in the English translation of the Law. especially promote and carry out the programs of joint and organized action and cooperation in combating maltreatment and abuse of children and youth, ... (Art. 37, p. 428); Issues of school functions and activities, its organization, method of work and house rules in school are defined by school general rules in accordance with the valid regulations, made in consultation with students (underlined by the author of this paper), parents and teachers.' (Art. 38, p. 428) [10].

The part related directly to pupils is contained in the provision number 10, within Art. 54, Students' Council, where it is clearly stated:

'Taking into consideration the age of students attending school, school helps them in establishing the students' council, with the function: a) to promote interests of school in a community the school is situated at; b) to represent the students' attitudes before the school board; c) to encourage engagement of students in school work; and d) to inform the school board on its attitudes whenever it considers it necessary, or upon the board request, on every issue related to work and management of school.' (p. 430) [10]

And it continues:

'Manner and procedure of establishment and work of students' council are determined by school rules.' (p. 430) [10]. So, pupils' views and voice should be heard at all levels of school functioning through Students' Council, according to this Law.

Although it may sound impressive at first sight, especially in the section on Students' Council, the law says one thing, and reality utters something else as will be seen later in this paper.

In The Concept of The Nine-Year Compulsory Education document (2004) [11], that refers to various UN and UNESCO documents on education, especially Learning: The Treasure Within (1994) [12], it is emphasized that cooperation between pupils and teachers must be realized within the process of learning and instruction. Although it focuses mainly on deeper involvement of the teachers and parents into school decision-making activities as well as on the partnership between school and parents, at a certain point it states that the school should teach pupils '... how to be ready to accept the role of being responsible active citizens (... how to represent equality and justice, ...)' (p. 8) [11].

Within section 9: Pupils [11], the focus is given to inclusive education, i.e. children with special needs and disabilities. However, there is no word about pupils without special needs, pupils' roles within the school or pupils as a relevant and active subject of inclusive and school education in general.

Furthermore, some parts of the Curriculum in the Croat language for primary schools in Bosnia and Herzegovina [13], approved in 2008, and closely based on the previously mentioned Concept of the nine-year compulsory primary school in Bosnia and Herzegovina (2004) [11], refer to pupils and inclusive schools. Beyond the statements focused on the prevention of any form of educational discrimination or marginalisation of pupils, fostering their competence 
according to Key Competences for Lifelong Learning (2004) [14] as well as their positive attitudes, opinions, motivation towards diversity, etc., is emphasized in the chapter 2 Goals and tasks of the education in primary schools in Bosnia and Herzegovina [13]:

'...pupil-oriented teaching and instruction... (p. 11), ...identification of pupils with developmental difficulties, their assistance and fostering sensibility of those without difficulties towards their needs, assistance and collaboration; ... introduction of mutual evaluation of pupils in the classroom; ...' (p. 12) [13].

In chapter 7 Particularities and implementation of curriculum it is explicitly stated that "children also learn from each other, so the group work and collaboration among children is important; ...' (p. 16) [13].

However, it may result from the paragraphs listed here that pupils' voice has been included to a certain extent in the curriculum, at least in its formal text. It will be interesting to see, later in this paper, pupils' opinion about their involvement.

Political rationale regards that the ideal approach is to 'act' as fast as possible. On the other hand, scientific rationale takes into account long-term results (outcomes, consequences) (Pavlović, Šarić, 2012) [15]. However, educational reform in Herzegovina-Neretva Canton has been implemented according to a top-down model which is reflected particularly within inclusive education. It should be remembered that neither educational reform nor inclusive education implies revolution, but rather the evolution of the educational system. The point is whether our schools are ready and prepared to accomplish this task.

Jimenez once stated 'if they give you ruled paper, write the other way...' [16]. These words concisely represent the outcome of our future schools: pupils as active subjects; incentives related to reflecting, understanding, contemplating, critical and divergent thinking, creativity, etc., all of these as the motivation, driving strength not only of teachers' but also pupils' involvement, acting and education.

\section{Research Methods}

The aim of the survey research, conducted in the two primary schools in the city of Mostar (Bosnia and Herzegovina) in the first half of 2014, was to examine the primary school pupils' attitudes towards inclusive education in general since very little similar researh has been conducted so far in our ocuntry. The research was carried out using a five-point Likert-type scale, consisting of 10 items, on a convenient, stratified sample of 300 pupils attending the final grade of the two primary schools in Mostar. The inquiry was performed during a school class (appr. 30 minutes), and in the presence of a school councellor for pupils only, with previous permission released by school principle. Besides answering the items, the pupils were given the possibility to write in the end of the attitude scale their suggestions regarding sex education as well as their message to the researcher in order to hear their 'voice'.

\section{Results}

The results of the research, hereby presented in the simplest descriptive way, through the figures observed, can serve as a kind of indicator for further research of this complex issue.

Table 1. Pupils' involvement in the implementation of inclusive education.

\begin{tabular}{|c|c|c|c|c|c|c|c|c|c|c|}
\hline & \multicolumn{2}{|c|}{ Strongly disagree } & \multicolumn{2}{|c|}{ Disagree } & \multicolumn{2}{|c|}{$\begin{array}{c}\text { Neither agree or } \\
\text { disagree }\end{array}$} & \multicolumn{2}{|c|}{ Agree } & \multicolumn{2}{|c|}{ Strongly agree } \\
\hline & $f$ & $\%$ & $f$ & $\%$ & $f$ & $\%$ & $f$ & $\%$ & $f$ & $\%$ \\
\hline $\begin{array}{l}\text { In school I attend I am informed enough about } \\
\text { inclusive education. }\end{array}$ & 84 & 28.0 & 113 & 37.66 & 52 & 17.33 & 30 & 10.0 & 21 & 7.0 \\
\hline $\begin{array}{l}\text { Teacher is responsible for the success of } \\
\text { inclusive education. }\end{array}$ & 18 & 6.0 & 29 & 9.66 & 65 & 21.66 & 112 & 37.33 & 76 & 25.33 \\
\hline $\begin{array}{l}\text { In our school we are being told about special } \\
\text { needs pupils. }\end{array}$ & 82 & 27.33 & 95 & 31.6 & 64 & 21.33 & 36 & 12.0 & 23 & 25.2 \\
\hline $\begin{array}{l}\text { Teachers should inform us (pupils) about } \\
\text { inclusion of special needs pupils into regular } \\
\text { schools. }\end{array}$ & 16 & 5.33 & 66 & 22.0 & 75 & 25.0 & 86 & 28.66 & 57 & 19.0 \\
\hline $\begin{array}{l}\text { No-one asks pupils' opinion about inclusion of } \\
\text { special needs pupil into regular schools. }\end{array}$ & 22 & 7.33 & 40 & 13.33 & 52 & 17.33 & 113 & 37.66 & 73 & 24.33 \\
\hline
\end{tabular}

(See Table 1) Almost two thirds of pupils attending the final grade of primary school in Mostar claim not to be informed enough about inclusive education. This is indicative if compared with the information regarding co-operation and partnership with pupils, too, which should have been fulfilled in a short term as emphasized in the most important educational documents analyzed earlier in this paper ${ }^{2}$. Although almost a half of pupils (without special needs) expected their teachers to inform them about inclusive education issues, more precisely about inclusion of special needs pupils into so-called regular schools that tend to be inclusive ones, almost $60 \%$ of them felt they did not get necessary information within their schools. One fourth of the pupils still do not have clear opinions about it.

2 Results of the author's previous reseasrch studies conducted on the samples of teachers (2010) [17] and parents (2012) [15] in Herzegovina-Neretva Canton showed that the most frequent obstacle to inclusive education was the lack of partnership among all the relevant subject, more precisely teachers, pedagogues, parents, higher educational institutions, i.e. colleges and faculties related to the teaching staff education, then institute of education, ministry of education as well as local community. Pupils were not taken in consideration in those research studies. 
Furthermore, almost two thirds of pupils put responsibility of successful inclusive education onto teachers' shoulders. They expect their teachers to play the main role in its implementation.

More than $60 \%$ of respondents claim they have never been asked their opinions about inclusive education. The pupils speak for themselves: 'I wish each pupil had the possibility to tell his/her suggestions freely.'; 'I wish pupils had better treatment in our school.'; 'Teachers and school itself should take into more consideration our (pupils') opinion.'

There is no wonder students feel this way since more than half of them are not being told in their school about special needs pupils. The lack of proper and timely information revealed in the author's previous research $(2010,2012)$ $[17,15]$ on the samples of primary and secondary teachers as well as parents of pupils with and without special needs, and now on pupils themselves, still remains the Gordian knot of inclusive school.

The pupils' negative attitudes are particularly evident regarding the issue of special needs pupils' benefit to the entire classroom (see Table 2). More than one half of the respondents claim that special needs pupils included in regular schools inhibit advancement of those without special needs. However, one fourth of them are still doubtful about this issue.

Almost one half of the respondents still claim that special needs pupils should attend special schools. Some of the pupils' comments were: 'I would expel special needs pupils from our school because they just inhibit other pupils' progress.'; 'All the special needs pupils should be sent to special schools instead of being together with us here. Why? Because some teachers are mocking both those pupils and us.'

As previously shown (see Table 1), due to the lack of appropriate information and the pupils' marginalization within their everyday school lives, their negative attitudes could be understood to a certain extent.

So, there is no wonder that their attitudes are almost equally distributed (slightly more than one third, respectively) about their willingness to attend the same class with special needs pupils included.

Almost one half of the final-year primary pupils' sample claimed that partnerships between teachers and pupils within inclusive education are not sufficient. It could be expected since they have been neglected in the planning and implementation of inclusive practices in the schools. Therefore, they mostly feel that special needs pupils should attend special schools. Pupils who participated in this research wrote: 'I would change the relationship between teachers and pupils, and among pupils themselves. There is something that does not work at all.'; 'Teachers should have more comprehension to us and our needs, too. '; 'Please, give us more projects in which pupils can participate, too.'; 'Please, more respect for us pupils.'; ; „I would ask our teachers for more comprehension towards pupils. They simply don't pay any attention to us... I wish our school introduced more activities in which pupils themselves could take an active part creating and improving them.'

Despite their negative attitudes slightly more than $60 \%$ of the respondents are willing to help special needs pupils when they are included in their class. However, in this issue the social desirability of pupils' responses should be kept in mind. It is clear that inclusive education without appropriately trained teaching staff, support, school and teachers' prior preparation, the commitment of all the involved subjects, including too often neglected pupils, staff (in-service) development, clear vision and free sharing of the ideas, opinions and experiences, partnerships of all the subjects, cannot work. However, the extent and success of its implementation will be critically uttered in the years still to come, through the benefits for the schools, teachers, parents and, most of all, pupils/children with and without special education needs (Pavlović, 2010) [17].

So, the question is posed: How can partnerships be emphasized within educational reform and its main documents, and what about contemporary schools and their care for all their subjects, in this case, pupils?!

Table 2. Pupils' attitude towards special needs pupils in inclusive schools.

\begin{tabular}{|c|c|c|c|c|c|c|c|c|c|c|}
\hline & \multicolumn{2}{|c|}{$\begin{array}{l}\text { Strongly } \\
\text { disagree }\end{array}$} & \multicolumn{2}{|c|}{ Disagree } & \multicolumn{2}{|c|}{$\begin{array}{c}\text { Neither agree or } \\
\text { disagree }\end{array}$} & \multicolumn{2}{|c|}{ Agree } & \multicolumn{2}{|c|}{ Strongly agree } \\
\hline & $f$ & $\%$ & $f$ & $\%$ & $f$ & $\%$ & $f$ & $\%$ & $f$ & $\%$ \\
\hline $\begin{array}{c}\text { Special needs pupils, included in regular } \\
\text { schools, inhibit development of pupils without } \\
\text { special needs. }\end{array}$ & 32 & 10.66 & 33 & 11.0 & 77 & 25.66 & 76 & 25.33 & 82 & 27.33 \\
\hline $\begin{array}{l}\text { I regard partnership between teachers and } \\
\text { pupils within inclusive education quite } \\
\text { sufficient. }\end{array}$ & 75 & 15.00 & 96 & 32.00 & 43 & 14.33 & 52 & 17.33 & 33 & 11.00 \\
\hline $\begin{array}{l}\text { I would like to attend the same class with the } \\
\text { special needs pupils. }\end{array}$ & 49 & 16.33 & 56 & 18.66 & 84 & 28.0 & 58 & 19.33 & 53 & 17.66 \\
\hline $\begin{array}{l}\text { In my opinion special needs pupils should be } \\
\text { educated in special schools and not regular } \\
\text { ones. }\end{array}$ & 15 & 5.0 & 61 & 20.33 & 81 & 27.0 & 58 & 19.33 & 85 & 28.33 \\
\hline $\begin{array}{l}\text { I am willing to help special needs pupils when } \\
\text { included in my class. }\end{array}$ & 27 & 9,0 & 37 & 12.33 & 53 & 17.66 & 96 & 32.0 & 87 & 29.0 \\
\hline
\end{tabular}




\section{Discussion}

Although inclusive education has its raison d'etre in the education reform in the Bosnia and Herzegovina, and thus in the Herzegovina-Neretva Canton, its top-down model could hardly boast success. As far as it concerns our country, inclusive education is focused mainly on the pupils with special needs (learning ones, mental difficulties, language speech problems, etc.) and not on the other strata of students.

It seems that pupils' voice and its strength have not been perceived as important factors in contemporary schools. Although 'young people are observant, are often capable of analytic and constructive comment, and usually respond well to the responsibility, seriously entrusted to them, of helping to identify aspects of schooling that strengthen and that get in the way of their learning' (Cox, 2005, p. 58) [6]. Pupils, i.e. their opinions and voice are usually excluded from decision-making and discussions about education, and school (Thomas, Walker \& Webb, 2005; Florian, 2005; Niemi, Heikkinen \& Kannas, 2010; Dutta, Banerjee, 2013; [18-21], etc.) respectively. Some of the projects based on pupils' voice to be heard are the one of Rudduck and co-workers (1997, according to Cox, 2005) [6] who emphasized the importance of pupils' views and experiences, and through the action research project supported (primary and secondary) schools' improvement. The European project Evaluating Quality in School Education" (MacBeath et al., 1998, according to Cox, 2005) [6] involving 101 schools is another good example. All of this can contribute to more inclusive school culture, as well. In that context, Robinson (2014) reflects upon 'a school's listening culture' (p. 23) [22], meaning 'listening to staff and pupils... and those who may not agree with the dominant cultural norms of school' (p. 23) [22], when dealing with important school issues. So far, there have not been many research studies conducted on pupils' voice in our schools, except one thorough paper (Lukenda, 2012) [23], on pupils' voice in general.

It is often forgotten that inclusive education is meant to meet the needs of all pupils, through one of the first and important prerequisites, i.e. pupils' involvement and their voice to be heard (Florian, 2005; Niemi, Heikkinen\&Kannas, 2010; Cambridge-Johnson, Hunter-Johnson\&Newton, 2014; Welsh Government, 2010) [19,20,24,25] bearing in mind '... the recognition of children as subjects of rights' (Pranevičienė\&Margevičiūtė, 2015, p. 131) [26]. Moreover, as Gordon (2015) [27] argued that the success of inclusive school should be perceived by hearing the recipients and participants of such a schooling in order to help schools develop inclusive practices. Bahou (2011) [28] also claimed that students' input is crucial for understanding inclusive school settings. Therefore, this paper reflected on pupils' opinions about inclusive education.

This research indicated somewhat negative attitudes of the respondents towards inclusion of special needs pupils into regular schools, as a result of the lack of appropriate information about inclusive education and its goals, opportunities and benefits for all the pupils as well as from their perception of being neglected in their school where their views and voice have been neither asked for nor heard although they expect their teachers to hear them. Although on some items in this research pupils still do not have clear attitude, they clearly indicated the points to be changed in schools on a daily basis, especially concerning teachers' and pupils' interaction as well as peers'. On the other hand their positive attitude is evident when asked about their willingness to help special needs pupils if included in the grades, i.e. schools they attend. In those terms, their willingness should be perceived as an important resource on which inclusive education could be built and/or improved in our schools. However, the point is not what approach, i.e. model of pupils' opinions and voice involvement into school everyday life is the best, but what combination of the approaches, i.e. various models is the most efficient and gives the long-term positive results, with particular regard to the benefit of children.

In the end, there are certain limitations of this research, and its results should be reflected with the caution. The research was conducted in the final-year primary school classes in which a small number of special needs pupils were enrolled. Another limitation is the approach itself. Qualitative research methodology, like the action research has seldom been implemented in the educational research studies in our country although it may be quite a good manner to deal with the complex issue as inclusive school is (Rudduck, 2007; Kane and Chimwayange, 2013) [29,30]. Special needs pupils' opinions and voice, where possible, should be examined and heard, as well, as Watson et al. (2000) [31] and Bishton (2007) [32] pointed in their research studies. However, the research presented in this paper could serve, as an ad hoc insight, for conducting future, better designed, research on pupils' views and voice on inclusive and education in general.

\section{Instead of Conclusion}

'Too often we find ourselves implementing policies that we do not value. Those of us in education need to take a stand and to serve as public advocates for our students. Who speaks for our students? We need to... And so I invite you to begin that conversation in your school, so that out of the collective wisdom of each of our communities can come a vision of education that our children deserve and, through that vision, the creation of the kind of schools that our children need." "' (Eisner, 2002, p. 583) [8]

Eisner's words clearly explain the position of pupils and their views and voice in our schools. The school that aims to become an inclusive one should be based on partnership of its crucial subject, and thus pupils, too. As Australian e5 model $^{3}$ comprised related to students' involvement: engage,

3 Although the e5 model deals primarily with sexual education, its stages could be taken into consideration when speaking about the ways

in which pupils' views and voice could be accounted for as the important and integral part of (inclusive) school everyday life. 
explore, explain, elaborate and evaluate (2011) [33]. To achieve this outcome, it is necessary to observe the inclusive school creation also through the lens of pupils themselves in order to move from the children-tailored-to-school concept towards the school-fit-to-children concept, i.e. from the concept of to what extent school has been inclusive towards the concept in what manners school can become inclusive.

\section{REFERENCES}

[1] W. Whitman. Leaves of Grass, Bantam Books, London, 1993.

[2] H. Bach. Osnove posebne pedagogije, Educa, Zagreb, 2005.

[3] H. Gudjons, H. Pedagogija - temeljna znanja, Educa, Zagreb, 1994.

[4] R. Medeghini, E. Valtellina. Quale disabilità? Culture, modelli e processi di inclusione, FrancoAngeli, Milano, 2006.

[5] M. F. Giangreco. Key Lessons Learned About Inclusive Education: summary of the 1996 Schonell Memorial Lecture, International Journal of Disability, Development and Education, Vol. 44, No. 3, 193-206, 1997.

[6] T. Cox. Pupils' perspectives on their education. In: K. Topping, S. Maloney (Eds.), The Routledge Farmer Reader in Inclusive Education, pp. 57-72, Routledge Farmer, Abingdon, Oxon, 2005.

[7] C. J. Marsh. Kurikulum, Educa, Zagreb, 1994.

[8] E. W. Eisner. The Kind of Schools We Need, Phi Delta Kappan, 83, No. 8, 576-583.

[9] Council for the Peace Agreement Implementation. Education reform: A message to the people of Bosnia and Herzegovina. Organisation for Security and Co-operation in Europe (OSCE), Brussels, 2002.

[10] Parliamentary Assembly of Bosnia and Herzegovina. Framework law on primary and secondary education in Bosnia and Herzegovina, Official Gazette BiH No. 18, 425-431, 2003.

[11] Ministry of Education of the Federation of Bosnia and Herzegovina. Concept of the Nine-year Compulsory Primary Education in Bosnia and Herzegovina, Official Gazette BiH No. 26, 412-426, 2004.

[12] International Commission on Education for the Twenty-first Century, J. Delors. Learning: The Treasure Within: Report to UNESCO of International Commission on Education for the Twenty-first Century, UNESCO Publishing, Paris, 1996.

[13] Ministarstvo prosvjete, znanosti, kulture i športa Kantona Središnja Bosna, Županije Zapadnohercegovačke, Županije Posavske, Hercegovačkoneretvanske Županije, Hercegobosanske Županije, Zavod za školstvo Mostar. Nastavni plan i program na hrvatskome jeziku za devetogodišnje osnovne škole u Bosni i Hercegovini, Multimedia Print, Nova Bila, 2008.

[14] Key Competences for Lifelong Learning: A European Framework, 2004. Online available from http://eur-lex-europa.eu/legal.content/EN
[15] S. Pavlović, M. Šarić. Partnership between school and parents - reality or illusion of inclusive education, Croatian Journal of Education, Vol. 14, No. 3, 511-522, 2012.

[16] J. R. Jimenez. Ja nisam ja, Izdavačko poduzeće "Rad", Beograd, 1977.

[17] S. Pavlović. Inclusive Education - Proclamations Or Reality (Primary School Teachers' View), USA-China Education Review, Vol. 7, No. 10, 62-69, 2010.

[18] G. Thomas, D. Walker, J. Webb. Inclusive education: the ideals and the practice. In: K. Topping, S. Maloney (Eds.), The Routledge Farmer Reader in Inclusive Education, pp. 17-28, Routledge Farmer, Abingdon, Oxon, 2005.

[19] L. Florian. Inclusive practice: what, why and how?. In: K. Topping, S. Maloney (Eds.), The Routledge Farmer Reader in Inclusive Education, pp. 29-40, Routledge Farmer, Abingdon, Oxon, 2005.

[20] R. Niemi, H.L.T. Heikkinen, L. Kannas. Polyphony in the classroom: reporting narrative action research reflexively, Educational Action Research, Vol. 18, No. 2, 137-149, 2010.

[21] J. Dutta, D. Banerjee. Inclusive Education: attitude and problems as perceived by the secondary school students, Indian Journal of Educational Research, Vol. II, 124-132, 2013.

[22] C. Robinson. Children, their voices and their experiences of school: what does the evidence tell us?, Cambridge Primary Review Trust, University of York, York, UK, 2014.

[23] A. Lukenda. Učenički glas, Suvremena pitanja, Vol. VI, No. 11-12, 34-43, 2011.

[24] J. Cambridge-Johnson, Y. Hunter-Johnson, N. G. L. Newton. Breaking the Silence of Mainstream Teachers' Attitude towards Inclusive Education in the Bahamas: High School Teachers' Perceptions. 2014. Online available from http://nsuworks.nova.edu/tqr/vol19/iss42/2

[25] LLywodraeth Cymru - Welsh Government. Pupil Participation - Good Practice Guide. 2010. Online available from

http://www.pupilvoicewales.org.uk/uploads/publications/540 .pdf

[26] B. Pranevičienè, A. Margevičiūtè, A. Challenges to the implementation of institutional reform in the Lithuanian general education system, Baltic Journal of Law \& Politics, Vol. 8, No. 1, 106-138, 2015.

[27] M. Gordon. Student Voice Key to Unlocking Inclusive Educational Practices, Canadian Journal for New Scholars in Education, Special Issue / Revue canadienne des jeunes chercheures et chercheurs en education, Vol. 3, No. 2, 1-11, 2010 .

[28] L. Bahou. Rethinking The Challenges and Possibilities of Student Voice and Agency, Educate Kaleidoscope Special Issue, North America, 2-14, 2011. Online available from http://www.educatejournal.org/index.php/educate/article/vie w/286

[29] J. Rudduck. Student Voice, Student Engagement, and School Reform, in D. Thiessen and A. Cook-Sather (eds) International Handbook of Student Experience in Elementary and Secondary School. Dordrecht: Springer, 587-610, 2007.

[30] R. G. Kane, C. Chimwayange. Teacher action research and 
student voice: Making sense of learning in secondary school. Action Research, Vol. 12, No. 1, 52-77, 2013.

[31] N. Watson et al. Life as a disabled child: A qualitative study of young people's experiences and perspectives, University of Leeds \& University of Edinburgh, Leeds and Edinburgh, UK, 2000.

[32] H. Bishton. Children's voice, children's rights. National
College for School Leadership. 2007. Online available from http://dera.ioe.ac.uk/7056/1/download\%3Fid\%3D17125\%26 filename $\% 3$ Dchildrens-voice-childrens-rights.pdf

[33] Department of Education and Early Child Development. Catching on Early Sexuality Education for Victorian Primary Schools, Department of Education and Early Child Development, State of Victoria, Melbourne, 2011. 